\title{
Synthesis and Characterization of Copper Substituted Nickel Nano-Ferrites by Citrate-Gel Technique
}

\author{
Rapolu Sridhar ${ }^{1}$, Dachepalli Ravinder ${ }^{2 *}$, K. Vijaya Kumar ${ }^{3}$ \\ ${ }^{1}$ Vignan's Institute of Technology \& Aeronautical Engineering College, Deshmukhi, India \\ ${ }^{2}$ Department of Physics, Osmania University, Hyderabad, India \\ ${ }^{3}$ Department of Physics, Jawaharlal Nehru Technological University College of Engineering, \\ Nachupally, India \\ Email: *ravindergupta28@rediffmail.com
}

Received June 23, 2012; revised July 26, 2012; accepted August 4, 2012

\begin{abstract}
Mixed copper substituted nickel nano-ferrites having the chemical formula $\mathrm{Ni}_{1-x} \mathrm{Cu}_{x} \mathrm{Fe}_{2} \mathrm{O}_{4}$ (where $x=0,0.2,0.4,0.6$, $0.8,0.9$ and 1.0) were synthesized by citrate gel technique. The crystal structure characterization and morphology were investigated by X-ray diffraction (XRD) and Scanning electron microscopy (SEM). An elemental composition of the samples were studied by energy dispersive X-ray Spectroscopy (EDS). Lattice parameter, X-ray density, Volume of the Unit Cell and The values of the hopping length for octahedral $\left(d_{\mathrm{B}}\right)$ and tetrahedral $\left(d_{\mathrm{A}}\right)$ sites were calculated. The observed results can be explained on the basis of composition.
\end{abstract}

Keywords: Ferrites; Nano-Materials; X-Ray Diffraction; SEM; EDS

\section{Introduction}

Nano crystalline spinel ferrites have been investigated in the recent years by many researchers. These ferrites are materials of interest because of their unique electric, dielectric and magnetic properties. These ferrites are very important group of magnetic materials due to their extensive use in a wide range of applications from low to high permeability devices including electronics, ferrofluid, magnetic drug delivery microwave devices, and high density information storage devices [1-5].

They have the general formula of $\mathrm{MFe}_{2} \mathrm{O}_{4}$ (where $\mathrm{M}$ (divalent metallic ion): $\mathrm{Fe}, \mathrm{Co}, \mathrm{Ni}, \mathrm{Cu}, \mathrm{Mg}$, etc.,) and a unit cell contains $32 \mathrm{O}$-atoms in a cubic close packing with 8Td (tetrahedral) (A site) and 16 Oh (octahedral) (B site) occupied sites [6]. In most ferrite materials, the substituents play an important role in determining the variation of the physical properties, the magnetic and electric transport properties are affected by the substitutents [7]. The substitution can be divided into the following types: direct replacement of $\mathrm{Fe}^{+3}$ on tetrahedral (A) or octahedral (B) sub lattice by the substituent ion, with conesquential redistribution of $\mathrm{Fe}^{+3}$ ions between $\mathrm{A}$ - and $\mathrm{B}-$ sub lattices which lead to the change of ferromagnetic spin structure. The extent of iron redistribution depends on the specific nature of the substituting ion. Many investigators have carried out research work on $\mathrm{Ni}$ ferrite

${ }^{*}$ Corresponding author. containing various cations such as $\mathrm{Zn}$ and $\mathrm{Cu}$ [7-13]. The substitution of $\mathrm{Cu}$ brings about a structural phase transition accompanied by the reduction in the crystal symmetry due to cooperative Jahn-Teller effect $[14,15]$, which ultimately results in some interesting electrical and magnetic properties.

Several investigators have focused their attention on $\mathrm{Ni}-\mathrm{Cu}$ ferrite because copper containing ferrites have interesting magnetic and electrical properties [16,17]. $\mathrm{Ni}-\mathrm{Cu}$ ferrites are preferred because of improved magnetic properties, high frequency response and high resistance. In the field of electronics, researchers continue to investigate the design of superstructures comprised of magnetically ordered arrays to enhance the sensitivity in magnetic sensors. The stability of electronic and high density data storage devices made by magnetic nanocomposites is limited by their super paramagnetic transition. Thus, while current efforts are aimed at increasing the thermal energy barrier against the magnetic reversal in magnetic nanocomposites, there is strong interest to understand the magnetization processes in the super paramagnetic region [18].

In the past, mixed spinel ferrites are prepared by conventional methods, which has disadvantages such as high period heating which may result in divalent volatilization and change the stoichiometry [19]. In recent years, numbers of physical and chemical techniques have been de- 
veloped to prepare nanosized materials. The chemical techniques for the synthesis of nanostructured materials offer some advantages in comparison with the physical techniques in relation to simplicity, energy saving and product homogeneity. The widely used chemical methods are electro deposition [20] sol-gel route [21], coprecipitation [22], micro emulsion technique [23], glyoxylate precursor method [24], hydrothermal method [25], reverse micelle technique [26], sucrose method [27, 28]. The citrate-gel auto combustion technique has been used for the preparation of mixed nanocrystalline spinel ferrites with specific properties, such as controlled stoichiometry and narrow particle size distribution. The low cost, simplicity and short time of production and the purity and homogeneity of final product are included among its advantages. In addition the speed and low temperature of the synthesis process prevent the sintering of the obtained powder; thus, it presents a large superficial area and a good sinterability in relation to powders obtained by other synthesis techniques [29-35].

\section{Experimental Details}

The mixed $\mathrm{Ni}-\mathrm{Cu}$ ferrite powders having the chemical formula $\mathrm{Ni}_{1-x} \mathrm{Cu}_{x} \mathrm{Fe}_{2} \mathrm{O}_{4}$ (where $x=0,0.2,0.4,0.5,0.6$, 0.8 and 1.0) were synthesized by citrate gel auto combustion technique using the below mentioned raw materials.

\subsection{Raw Materials}

- Nickel Nitrate-99\%Pure (AR Grade) $\left(\mathrm{Ni}\left(\mathrm{No}_{3}\right)_{2} 6 \mathrm{H}_{2} \mathrm{O}\right)$

- Copper Nitrate-99\%Pure (AR Grade) $\left(\mathrm{Cu}\left(\mathrm{No}_{3}\right)_{2} 3 \mathrm{H}_{2} \mathrm{O}\right)$

- Ferric Nitrate-99\%Pure (AR Grade) $\left(\mathrm{Fe}\left(\mathrm{No}_{3}\right)_{2} 9 \mathrm{H}_{2} \mathrm{O}\right)$

- Citric Acid-Citrate-99\%Pure (GR Grade) $\left(\mathrm{C}_{6} \mathrm{H}_{8} \mathrm{O}_{7} \mathrm{H}_{2} \mathrm{O}\right)$

- Ammonia-99\% Pure(AR Grade) $\left(\mathrm{NH}_{3}\right)$

\subsection{The Flow Chart for Synthesis of $\mathrm{Ni}-\mathrm{Cu}$ Ferrites}

Preparation of the mixed $\mathrm{Ni}-\mathrm{Cu}$ ferrite powders were synthesized by citrate gel technique using the below mentioned flowchart:

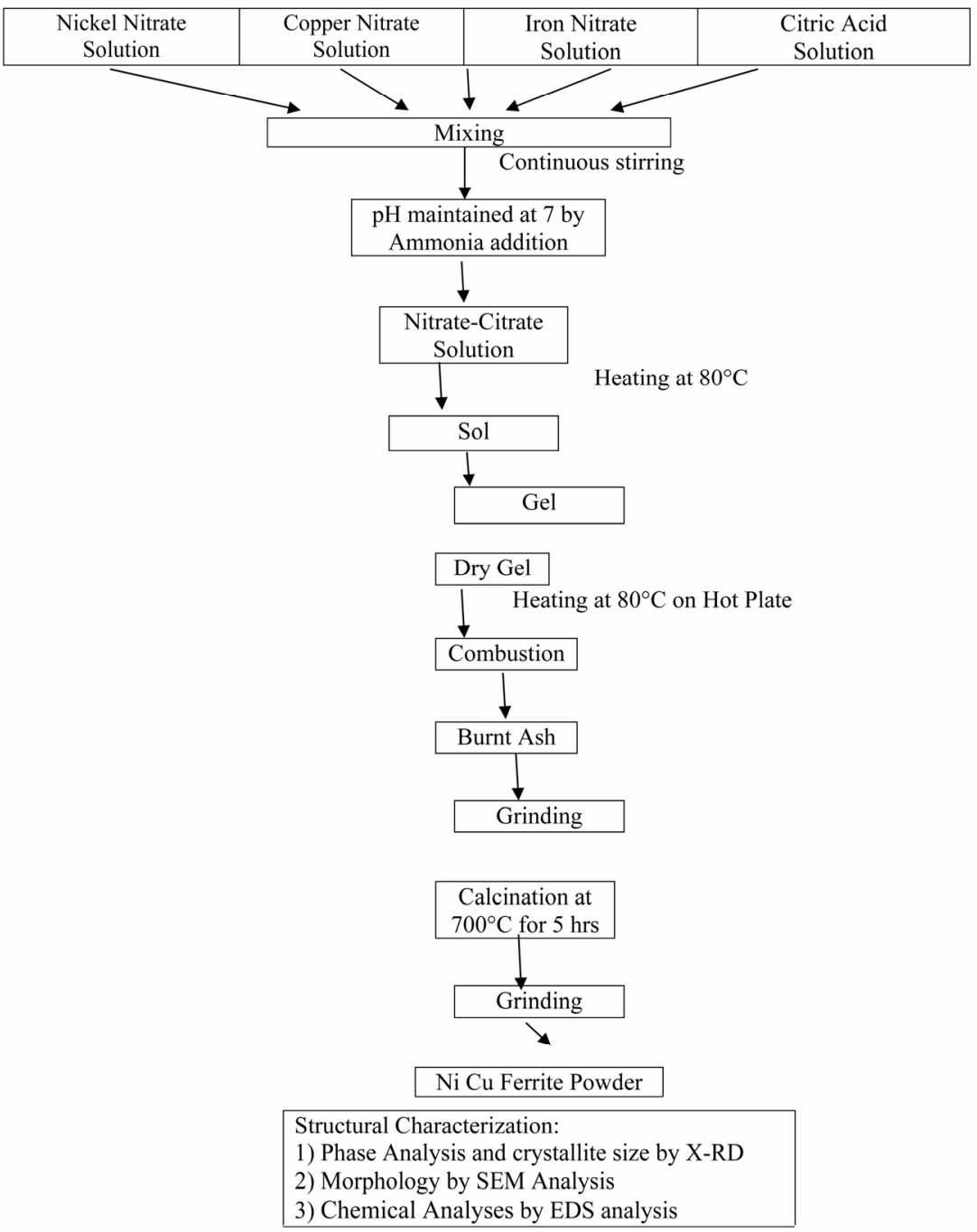




\section{Results and Discussion}

\subsection{Structural Characterization}

The structural characterization was carried out using the X-ray diffractomerter Bruker (Karlsruhe, Germany) D8 advanced system with a diffracted beam monochromatic $\mathrm{Cu} \mathrm{K} \mathrm{K}_{\alpha}$ radiation $(\lambda=1.5405 \AA)$ radiation source between the Bragg Angles $20^{\circ}$ to $80^{\circ}$ in steps of $0.04^{\circ} / \mathrm{Sec}$. The $2 \theta$ vs. intensity data obtained from this experiment and plotted a graph as shown in Figure 1.

The X-ray diffraction pattern, crystalline phases were identified by comparison with PDF-4 reference data from the international centre for diffraction data (ICDD). All Bragg reflections have been indexed, which confirm the formation of cubic spinel structure in single phase without any impurity peak. The strongest reflection comes from the (311) plane, which denotes the spinel phase. The peaks indexed to (111), (220), (311), (400), (511) and (440) planes of a cubic unit cell, all planes are the allowed planes which indicates the formation of cubic spinel structure in single phase [36].

The crystallite size was calculated for the all the compositions using the high intensity 311 peak and using Scherrer Formula [37] while taking into account the instrumental broading [38].

$$
D_{h k l}=\frac{0.91 \lambda}{\beta \cos \theta}
$$

where $D_{h k l}$ is the crystalline size perpendicular to $(h k l)$ pane,

$\lambda$ : the wave length of X-ray [39] used,

$\beta$ : width of diffraction peak i.e., Full Width Half Maxima (FWHM)

$\theta$ : the peak position.

The calculated values of crystallite size for the different compositions are given in Table 1.

It can be seen from the table that the values of the crystal size veries from $36.7 \mathrm{~nm}$ to $58.91 \mathrm{~nm}$. Though all

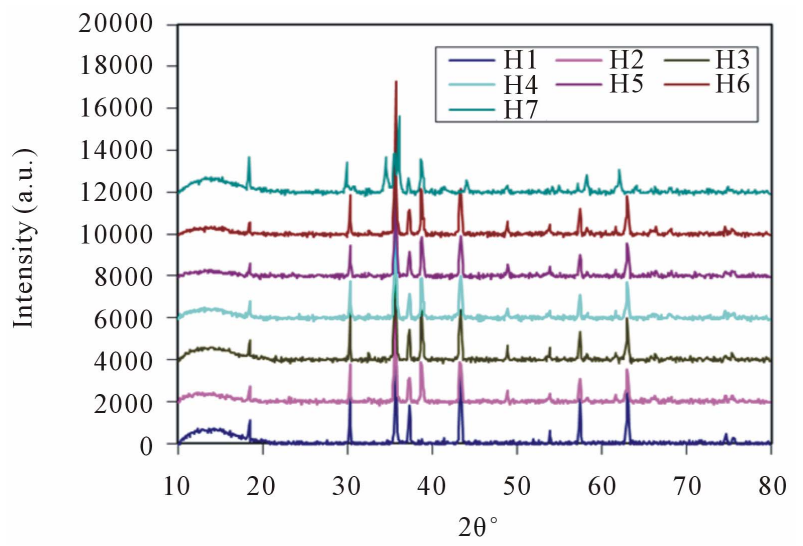

Figure 1. X-ray diffraction pattern of Ni-Cu nano ferrites (with $x=0,0.2,0.4,0.5,0.6,0.8$ and 1.0). the samples were prepared under identical condition, the crystallite size was not the same for all $\mathrm{Cu}$ concentrations. This was probably due to the preparation condition followed here which gave rise to different rate of ferrite formation for different concentrations of $\mathrm{Cu}$, favoring the variation of crystallite size. Conventional methods need to high temperatures and prolonged heating time [40,41], but in this method, ferrite phase can produce very fast at low temperature.

The values of lattice parameter (a) for all the compositions of $\mathrm{Ni}-\mathrm{Cu}$ nano ferrites have been calculated from the values of d-Spacings and are given in Table 1 .

The lattice parameter (a) of individual composition was calculated by using the formula

$$
a=d \sqrt{h^{2}+k^{2}+l^{2}} \AA[42]
$$

where $a=$ Lattice Constant

$(h k l)$ are the Miller Indices,

$d$ is inter planner spacing.

A plot of lattice parameter (a) vs. $\mathrm{Cu}$ ion content (composition) is shown in Figure 2.

It can be seen from the Figure 2 that the lattice parameter decreases with the increasing $\mathrm{Cu}$ substitution in $\mathrm{Ni}$ ferrites, the variation may be attributed to the ionic size difference between $\mathrm{Cu}^{+2}(0.73 \AA)$ and $\mathrm{Ni}^{+2}(0.69 \AA)$ where $\mathrm{Cu}^{+2}$ ion replaces $\mathrm{Ni}^{+2}$ ion on $\mathrm{B}$ site high ionic radius $\mathrm{Cu}^{+2}(0.73 \AA)$ is substituted in the low ionic radius $\mathrm{Ni}^{+2}(0.69 \AA)$ place, that the mixed Ni-Cu ferrite system obeys Vegard's law [43]. The lattice parameter is found to decrease, which may be attributed to shifting on some $\mathrm{Fe}^{3+}$ ions form $\mathrm{A}$ site to $\mathrm{B}$ site for higher composition [36]. The average value of lattice parameter of all compositions is $8.313 \AA$ which is close to $8.345 \AA$ i.e. the reported value for bulk sample of mixed $\mathrm{Ni}-\mathrm{Cu}$ ferrite [44].

The X-ray density $\left(d_{x}\right)$ was computed from the values of lattice parameter (a) using the formula is

$$
\text { X-ray density }\left(d_{x}\right)=\frac{8 M}{N a^{3}}\left[\mathrm{~g} / \mathrm{cm}^{3}\right] \text { [45] shown in }
$$

\section{Table 1.}

Where 8 represents the number of moleules in a unit cell of spinel lattice,

$M$ is the molecular weight of composition,

$N$ is the Avogadro's number a is lattices parameter

A plot of the X-ray density $\left(d_{x}\right) \mathrm{Vs} \mathrm{Cu}$ ion content (composition) is shown in Figure 3.

It can be seen from the Figure 3 that the X-ray density $\left(d_{x}\right)$ increases with the increasing $\mathrm{Cu}$ substitution in $\mathrm{Ni}$ Ferrites, it shows the densification of the material. The $\mathrm{X}$-ray density is found to depend on the lattice parameter and molecular weight of the samples, hence the substituting $\mathrm{Cu}^{+2}$ is increase lattice parameter decreases and $\mathrm{X}$-ray density increases. 


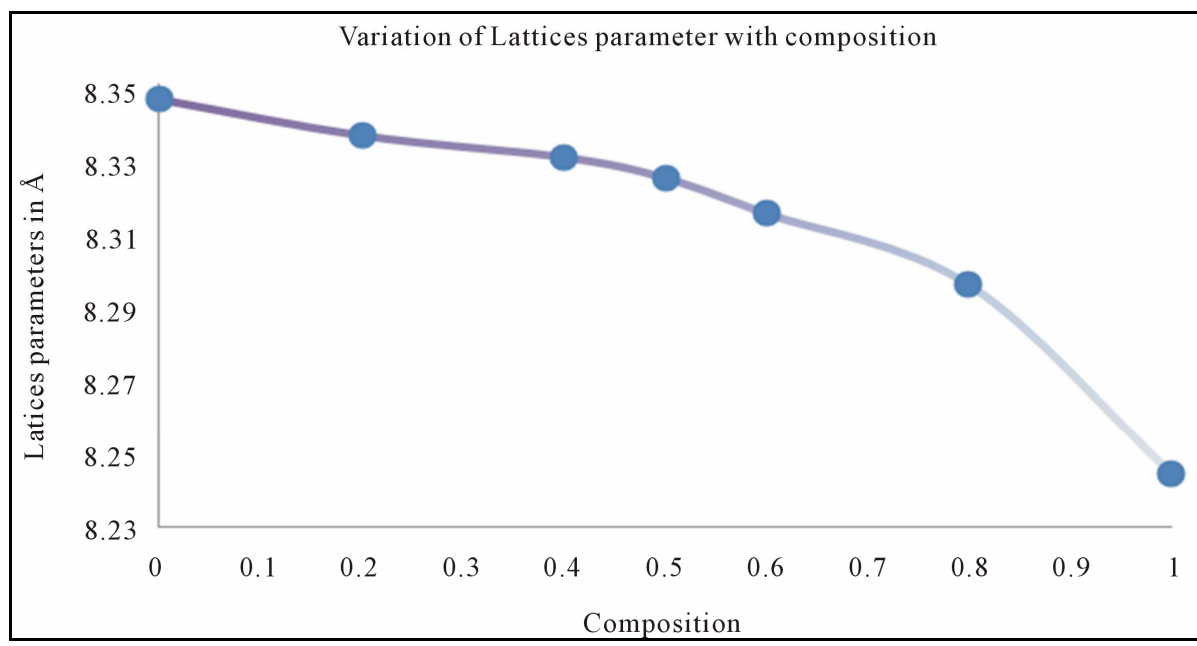

Figure 2. Graph between the lattice parameter (a) vs. Cu ion content (composition).

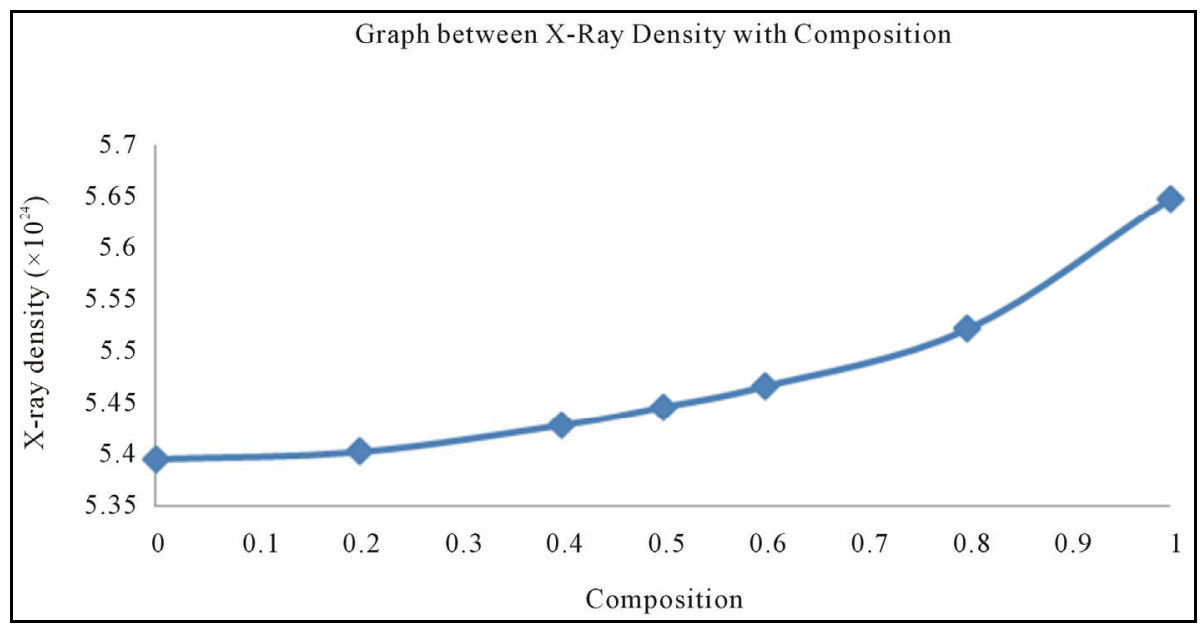

Figure 3. Graph between the X-ray density $\left(d_{x}\right)$ vs. Cu ion content (composition).

Table 1. Values of crystallite size, lattice parameter (a), d-spacing (d), X-ray density $\left(d_{x}\right)$ and hopping length for A-site $\left(d_{\mathrm{A}}\right)$ and B-site $\left(d_{\mathrm{B}}\right)$ of Ni-Cu nano ferrite (with $x=0,0.2,0.4,0.5,0.6,0.8$ and 1.0) with $2 \theta$ (degrees) and $\beta$ (degrees) (FWHW).

\begin{tabular}{|c|c|c|c|c|c|c|c|c|c|}
\hline Sl. No. & $\begin{array}{l}\text { Sample } \\
\text { (X Value) }\end{array}$ & $2 \theta$ (degrees) & $\begin{array}{c}\beta \text { (degrees) } \\
\text { (FWHW) }\end{array}$ & $\begin{array}{l}\text { Crystallite } \\
\text { size (nm) }\end{array}$ & $\begin{array}{c}\text { Lattice } \\
\text { parameter in Å (a) }\end{array}$ & $\begin{array}{c}\text { X-ray density } \\
\left(d_{x}\right)\left[\mathrm{g} / \mathrm{cm}^{3}\right]\end{array}$ & $\begin{array}{l}\text { Volume of unit } \\
\text { cell }(\mathrm{V})(\AA)^{3}\end{array}$ & A-site $\left(d_{A}\right)$ & B-site $\left(d_{\mathrm{B}}\right)$ \\
\hline 1 & $H_{1}(x=0)$ & 35.695 & 0.1419 & 58.91 & 8.345 & $5.396 \times 10^{24}$ & 581.32 & 2.950 & 3.614 \\
\hline 2 & $\mathbf{H}_{2}(x=0.2)$ & 35.680 & 0.1802 & 46.3 & 8.336 & $5.403 \times 10^{24}$ & 579.28 & 2.947 & 3.610 \\
\hline 3 & $\mathbf{H}_{3}(x=0.4)$ & 35.681 & 0.1694 & 49.2 & 8.330 & $5.429 \times 10^{24}$ & 578.06 & 2.944 & 3.607 \\
\hline 4 & $\mathbf{H}_{4}(x=0.5)$ & 35.683 & 0.2236 & 37.3 & 8.324 & $5.447 \times 10^{24}$ & 576.88 & 2.942 & 3.604 \\
\hline 5 & $\mathbf{H}_{5}(x=0.6)$ & 35.690 & 0.2257 & 36.9 & 8.315 & $5.467 \times 10^{24}$ & 574.89 & 2.939 & 3.600 \\
\hline 6 & $\mathbf{H}_{6}(x=0.8)$ & 35.678 & 0.1925 & 43.33 & 8.295 & $5.522 \times 10^{24}$ & 570.89 & 2.932 & 3.592 \\
\hline 7 & $\mathbf{H}_{7}(x=1)$ & 36.059 & 0.2274 & 36.7 & 8.244 & $5.648 \times 10^{24}$ & 560.37 & 2.914 & 3.57 \\
\hline
\end{tabular}

The volume of the unit cell $\mathrm{V}=\mathrm{a}^{3}(\AA)^{3}$.

Calculated values are shown in Table 1 the volume of the unit cell is decreases with increasing the $\mathrm{Cu}$ Substitution in Ni Ferrite, because the lattice Parameter is decreases with increasing the $\mathrm{Cu}$ Substitution in Ni Ferrite.

Figure 3 also indicate that the X-ray density $\left(d_{x}\right)$ increases with the increase in $\mathrm{Cu}$ ion content, this can be 
ascribed to the atomic weight and density of $\mathrm{Cu}^{+2}$ $\left(63.546,8.96 \mathrm{gm} / \mathrm{cm}^{3}\right)$ which are higher than those of nickel $\left(53.933,8.91 \mathrm{gm} / \mathrm{cm}^{3}\right)$. The X-ray density of nickel ferrite was in good agreement with earlier reported values $5.38 \mathrm{gm} / \mathrm{cm}^{3}$ [46]. The distance between magnetic ions on B and A Sites is calculated according to the following relations [47].

$$
d_{\mathrm{B}}=0.25 a \sqrt{2} \text { and } d_{\mathrm{A}}=0.25 a \sqrt{3}
$$

where $(a)$ is the lattice parameter

The values of the hopping length for octahedral $\left(d_{\mathrm{B}}\right)$ and tetrahedral $\left(d_{\mathrm{A}}\right)$ sites are listed in Table 1. It is clear that the distance between the magnetic ions increases as the $\mathrm{Cu}^{+2}$ content increases.

\subsection{Morphological and Chemical Analyses}

The morphological and chemical analyses were performed using SEM (Scanning Electron Microscope with an Energy Dispersive Spectrometer (EDS). The Secondary electron images were taken at different magnifications to study the morphological and their Composition of elements of each sample analyzed by (\% in weight), obtaied using EDS, chemical compositions were determined by processing the corresponding K-line spectra obtained with an incident beam of $10 \mathrm{KeV}$ electrons. A standardless semi-quantitative analysis was performed for this purpose.

It can seen from SEM micrographs various compo- sitions that the morphology of the particles is very similar. They indicate that the particle size of the samples lies in the nanometer regine having a sperical shape and a narrow size distribution. The particle sharpness is more or less spherical with some cluster/agglomeration between the particles.

The EDS pattern obtained for all the samples which gives the elemental\% and atomic \% composition in samples shown in Table 2. The elements detected in all the samples were $\mathrm{O}, \mathrm{Fe}, \mathrm{Ni}, \mathrm{Cu}$; the presence of Carbon element is mainly due to the coating applied on the samples prior to the SEM-EPMA (Electron Probe microanalysis) analysis.

\section{Conclusions}

- The citrate-Gel auto combution technique to be a conveniant and varsalite for obtaining homogeneous and reactive nanostructured mixed $\mathrm{Ni}-\mathrm{Cu}$ ferrites. No impurity peak or material loss during processing.

- X-ray diffraction pattern confirm that the formation of single phase cubic spinel structure. The crystallite size of the nano ferrites in the range $36-58 \mathrm{~nm}$.

- The lattice parameter is decreases with the increase of $\mathrm{Cu}$ substitution in $\mathrm{Ni}$ ferrites indicate that the mixed $\mathrm{Ni}-\mathrm{Cu}$ ferrite system obeys Vegard's law.

- X-ray density increases with of increase of $\mathrm{Cu}$ substitution in $\mathrm{Ni}$ ferrites shows the densification of the material.
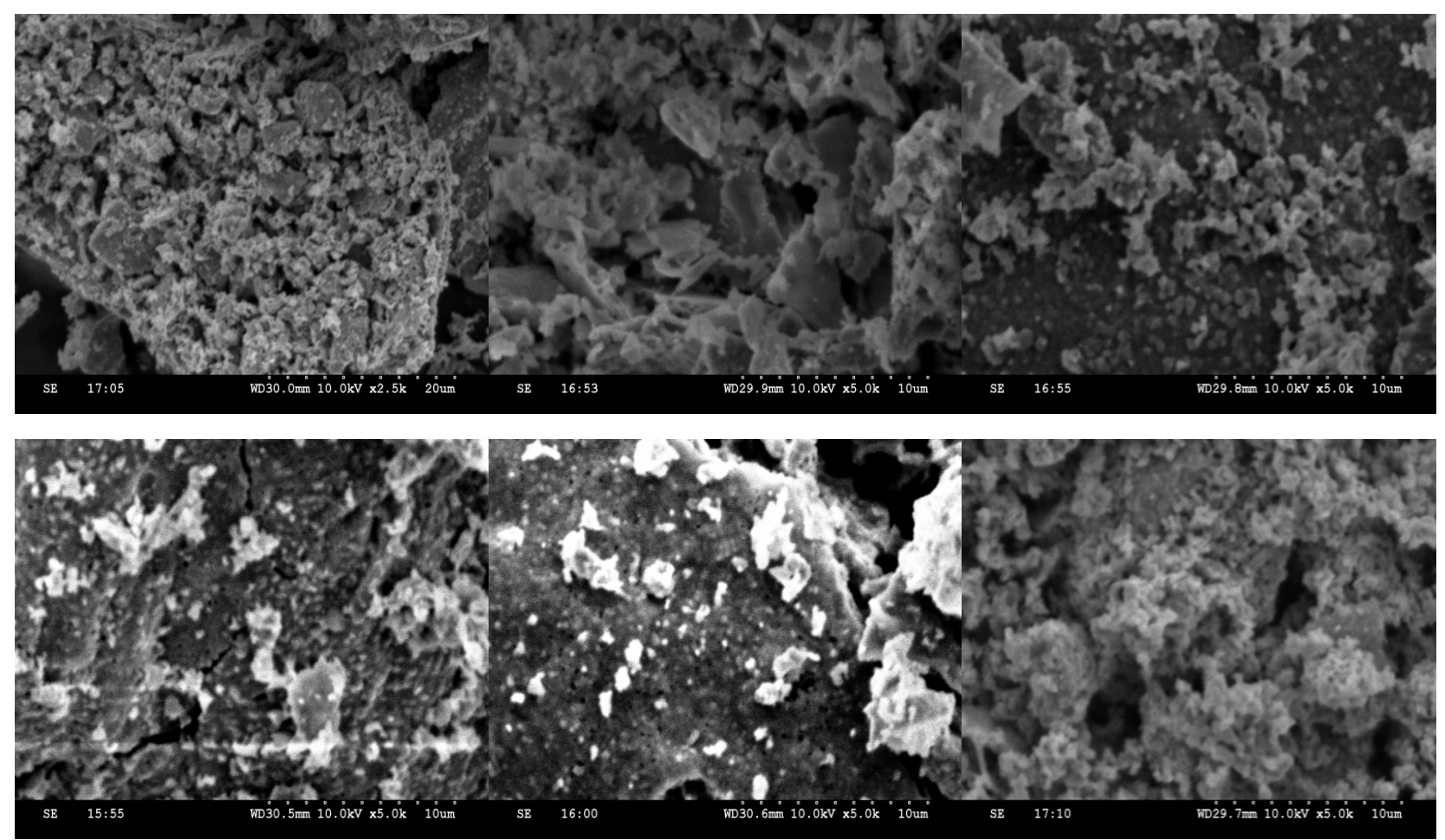

Figure 4. SEM micrographs of compositions of $\mathrm{Ni}-\mathrm{Cu}$ nano ferrite (with $x=0,0.2,0.4,0.5,0.6,0.8$ and 1.0). 
Table 2. Composition of elements of each sample analyzed by (\% in weight), obtaied using EDS.

\begin{tabular}{|c|c|c|c|c|c|c|c|c|c|c|c|c|c|c|}
\hline Composition & \multicolumn{2}{|c|}{$\mathrm{H}_{1}(x=0)$} & \multicolumn{2}{|c|}{$\mathrm{H}_{2}(x=0.2)$} & \multicolumn{2}{|c|}{$\mathrm{H}_{3}(x=0.4)$} & \multicolumn{2}{|c|}{$\mathrm{H}_{4}(x=0.5)$} & \multicolumn{2}{|c|}{$\mathrm{H}_{5}(x=0.6)$} & \multicolumn{2}{|c|}{$\mathrm{H}_{6}(x=0.8)$} & \multicolumn{2}{|c|}{$\mathrm{H}_{7}(x=1)$} \\
\hline Element & $\begin{array}{c}\text { Element } \\
\%\end{array}$ & $\begin{array}{c}\text { Atomic } \\
\%\end{array}$ & $\begin{array}{c}\text { Element } \\
\%\end{array}$ & $\begin{array}{c}\text { Atomic } \\
\%\end{array}$ & $\begin{array}{c}\text { Element } \\
\%\end{array}$ & $\begin{array}{c}\text { Atomic } \\
\%\end{array}$ & $\begin{array}{c}\text { Element } \\
\%\end{array}$ & $\begin{array}{c}\text { Atomic } \\
\%\end{array}$ & $\begin{array}{c}\text { Element } \\
\%\end{array}$ & $\begin{array}{c}\text { Atomic } \\
\%\end{array}$ & $\begin{array}{c}\text { Element } \\
\%\end{array}$ & $\begin{array}{c}\text { Atomic } \\
\%\end{array}$ & $\begin{array}{c}\text { Element } \\
\%\end{array}$ & $\begin{array}{c}\text { Atomic } \\
\%\end{array}$ \\
\hline $\mathrm{C}$ & 5.58 & 14.97 & - & - & 4.73 & 9.19 & - & - & 0.12 & 0.38 & 5.49 & 15.07 & - & - \\
\hline $\mathrm{O}$ & 21.95 & 44.20 & 22.06 & 40.87 & 22.43 & 32.74 & 16.16 & 41.71 & 20.09 & 48.12 & 21.34 & 43.94 & 21.86 & 50.94 \\
\hline $\mathrm{Ni}$ & 34.26 & 18.80 & 20.24 & 20.16 & 24.04 & 19.37 & 27.35 & 19.24 & 26.87 & 17.54 & 24.46 & 13.94 & - & - \\
\hline $\mathrm{Cu}$ & - & - & 22.50 & 20.27 & 25.80 & 19.38 & 30.00 & 19.82 & 28.10 & 16.94 & 26.50 & 13.74 & 38.39 & 22.52 \\
\hline
\end{tabular}

- The distance between magnetic ions on B and A Sites is calculated. It is clear that the distance between the magnetic ions increases as the $\mathrm{Cu}^{2+}$ content increases.

- SEM analyses explain that the morphology of the particles is very similar. The particle sharpness is more or less spherical with some cluster/agglomeration between the particles.

- EDS data gives the elemental \% and atomic \% in the composition of mixed $\mathrm{Ni}-\mathrm{Cu}$ ferrites, and it shows the presence of $\mathrm{Ni}, \mathrm{Cu}, \mathrm{Fe}$ and $\mathrm{O}$ without precipitating cations.

\section{Acknowledgements}

The authors are grateful Prof. P. Kistaiah, head, Department of Physics, Osmania University, Hyderabad for his encouragement in research work. One of the authors R. Sridhar is grateful to Prof. N. Venkateswarlu Principal, Vignan's Institute of Technology \& Aeronautical Engineering College, Hyderabad. And the author K. Vijaya Kumar is grateful to Dr. Koorapati Eshwara Prasad, Principal JNTUH College of Engineering, Nachupally, Karim Nagar (Dist).

\section{REFERENCES}

[1] Y. Qu, H. Yang, N. Yang, Y. Fan, H. Zhu and G. T. Zou, "The Effect of Reaction Temperature on the Particle Size, Structure and Magnetic Properties of Coprecipitated $\mathrm{CoFe}_{2} \mathrm{O}_{4}$ Nanoparticles," Materials Letters, Vol. 60, No. 29-30, 2006, pp. 3548-3552. doi:10.1016/j.matlet.2006.03.055

[2] P. L. Phillips, J. C. Knight, B. J. Mangan, P. St. J. Russell, M. D. B. Charlton and G. J. Parker, "Near-Field Optical Microscopy of Thin Photonic Crystal Films," Journal of Applied Physics, Vol. 85, No. , 1999, pp. 6338-6345.

[3] M. H. Sousa and F. A. Tourinho, "New Electric Dou- bleLayered Magnetic Fluids Based on Copper, Nickel, and Zinc Ferrite Nanostructures," The Journal of Physical Chemistry B, Vol. 105, No. 6, 2001, pp. 1168-1175. doi:10.1021/jp0039161

[4] F. Mazaleyrat and L. K. Varga, "Ferromagnetic Nanocomposites," Journal of Magnetism and Magnetic Mate- rials, Vol. 215-216, 2000, pp. 253-259. doi:10.1016/S0304-8853(00)00128-1

[5] D. E. Speliotis, "Magnetic Recording beyond the First 100 Years," Journal of Magnetism and Magnetic Materials, Vol. 93, No. 1-3, 1999, pp. 29-35. doi:10.1016/S0304-8853(98)00399-0

[6] Y. Cheng, Y. Zheng, Y. Wang, F. Bao and Y. Qin, "Synthesis and Magnetic Properties of Nickel Ferrite NanoOctahedra," Journal of Solid State Chemistry, Vol. 178, No. 7, 2005, pp. 2394-2397. doi:10.1016/j.jssc.2005.05.006

[7] P. K. Roy, B. B. Nayak and J. Bera, "Study on ElectroMagnetic Properties of La Substituted Ni-Cu-Zn Ferrite Synthesized by Auto-Combustion Method," Journal of Magnetism and Magnetic Materials, Vol. 320, No. 6, 2008, pp. 1128-1132. doi:10.1016/j.jmmm.2007.10.025

[8] P. A. Jadhav, R. S. Devan, Y. D. Kolekar and B. K. Chougule, "Structural, Electrical and Magnetic Characterizations of Ni-Cu-Zn Ferrite Synthesized by Citrate Precursor Method," Journal of Physics and Chemistry of Solids, Vol. 70, No. 2, 2009, pp. 396-400. doi:10.1016/j.jpcs.2008.11.019

[9] M. A. Gabal, "Effect of Mg Substitution on the Magnetic Properties of NiCuZn Ferrite Nanoparticles Prepared through a Novel Method Using Egg White," Journal of Magnetism and Magnetic Materials, Vol. 321, No. 19, 2009, pp. 3144-3148. doi:10.1016/j.jmmm.2009.05.047

[10] J. Slama. A. Gruskova, M. Usakova, E. Usak and R. Dosoudil, "Analysis of Cu-Substituted NiZn Ferrites," Journal of Magnetism and Magnetic Materials, Vol. 321, No. 19, 2009, pp. 3346-3351.

[11] M. A. Ahmed, A. A. I. Khalil and S. Solyman, "Laser Induced Structural and Transport Properties Change in Cu-Zn Ferrites," Journal of Materials Science, Vol. 42, No. 11, 2007, pp. 4098-4109. doi:10.1007/s10853-006-1151-z

[12] S. A. Mazen, M. A. Ahmed and B. A. Sabra, "Thermal Studies on the Electrical Conduction Mechanism of $\mathrm{CuFe}_{2} \mathrm{O}_{4}$," Physica Status Solidi (a), Vol. 70, No. 1, 1982, pp. K71-K75. doi:10.1002/pssa.2210700158

[13] M. A. Ahmed, N. Okasha and L. Salah, "Influence of Yttrium Ions on the Magnetic Properties of Ni-Zn Ferrites," Journal of Magnetism and Magnetic Materials, Vol. 264, No. 2-3, 2003, pp. 241-250. doi:10.1016/S0304-8853(03)00212-9 
[14] M. C. Dimri, A. K. Verma, S. C. Kashyap, D. C. Dube and O. P. Thakur, "Structural, Dielectric and Magnetic Properties of NiCuZn Ferrite Grown by Citrate Precursor Method," Materials Science and Engineering: B, Vol. 133, No. 1-3, 2006, pp. 42-48. doi:10.1016/j.mseb.2006.04.043

[15] A. Verma, T. C. Goal, R. G. Mendiratta and P. Kishan, "Magnetic Properties of Nickel-Zinc Ferrites Prepared by the Citrate Precursor Method," Journal of Magnetism and Magnetic Materials, Vol. 208, No. 1-2, 22000, pp. 13-19. doi:10.1016/S0304-8853(99)00585-5

[16] N. Nanba and S. Kobayashi, "Semiconductive Properties and Cation Distribution of Copper Ferrites $\mathrm{Cu}_{1-\delta} \mathrm{Fe}_{2+\delta} \mathrm{O}_{4}$," Japanese Journal of Applied Physics, Vol. 17, 1978, pp. 1819-1823. doi:10.1143/JJAP.17.1819

[17] S. R. Sawant and R. N. Patil, "Magnetic Hysteresis Studies on Slow Cooled and Quenched $\mathrm{Cu}_{x} \mathrm{Zn}_{1-x} \mathrm{Fe}_{2} \mathrm{O}_{4}$ System," Solid State Communications, Vol. 40, No. 4, 1981, pp. 391-394. doi:10.1016/0038-1098(81)90845-0

[18] I. W. Park, M. Yoon, Y. M. Kim, Y. Kim, H. Yoon, H. J. Song, V. Volkov, A. Avilov and Y. J. Park, "Magnetic Properties and Microstructure of Cobalt Nanoparticles in a Polymer Film," Solid State Communications, Vol. 126, No. 7, 2003, pp. 385-389. doi:10.1016/S0038-1098(03)00189-3

[19] E. E. Sileo, R. Rotelo and S. E. Jacobo, "Nickel Zinc Ferrites Prepared by Citrate Precursor Method," Journal of Physics B, Vol. 320, No. 1-4, 2002, pp. 257-260. doi:10.1016/S0921-4526(02)00705-6

[20] U. Erb, "Electrodeposited Nanocrystals: Synthesis, Properties and Industrial Applications," Nanostructured Materials, Vol. 6, No. 5, 1995, pp. 533-538.

[21] A. Chatterjee, D. Das, S. K. Pradhan and D. Chakravarty, "Synthesis of Nanocrystalline Nickel-Zinc Ferrite by the Sol-Gel Method," Journal of Magnetism and Magnetic Materials, Vol. 127, No. 1-2, 1993, pp. 214-218. doi:10.1016/0304-8853(93)90217-P

[22] M. Pal and D. Chakravorty, "Nanocrystalline Magnetic Alloys and Ceramics," Sadhana, Vol. 28, No. 1-2, 2003, pp. 283-297.

[23] J. Chargles, N. O'Connor, E. Kolesnichenko, C. Carpenter, S. W. Zheu, A. Kumbhar, S. Jessica and A. Fabrice, "Fabrication and Properties of Magnetic Particles with Nanometer Dimensions," Synthetic Metals, Vol. 122, No. 3, 2001, pp. 547-555. doi:10.1016/S0379-6779(01)00328-9

[24] C. Caizer and M. Stefanescu, "Magnetic Characterization of Nanocrystalline Ni-Zn Ferrite Powder Prepared by the Glyoxylate Precursor Method," Journal of Physics D: Applied Physics, Vol. 35, No. 23, 2002, pp. 3035-3040. doi:10.1088/0022-3727/35/23/301

[25] A. Dias, "Microstructural Evolution of Fast-Fired NickelZinc Ferrites from Hydrothermal Nanopowders," Materials Research Bulletin, Vol. 35, No. 9, 2000, pp. 14391446. doi:10.1016/S0025-5408(00)00337-8

[26] S. Gubbala, H. Nathani, K. Koizol and R. D. K. Misra, "Magnetic Properties of Nanocrystalline Ni-Zn, Zn-Mn, and Ni-Mn Ferrites Synthesized by Reverse Micelle
Technique," Physica B, Vol. 348, No. 1-4, 2004, pp. 317 328. doi:10.1016/j.physb.2003.12.017

[27] P. Pramanik, "A Novel Chemical Route for the Preparation of Nanosized Oxides, Phosphates, Vanadates, Molybdates and Tungstates Using Polymer Precursors," Bulletin of Materials Science, Vol. 22, No. 3, 1999, pp. 335339. doi:10.1007/BF02749940

[28] R. N. Das, "Nanocrystalline Ceramics from Sucrose Process," Materials Letters, Vol. 47, No. 6, 2001, pp. 344-350. doi:10.1016/S0167-577X(00)00264-0

[29] S. Biamino and C. Badini, "Comhustion Synthesis of Lanthanum Chromite Starting Form Water Solution: Investigation of Process Mechanism by DTA-TGA-Ms," Journal of the European Ceramic Society, Vol. 24, No. 10-11, 2004, pp. 3021-3034.

doi:10.1016/j.jeurceramsoc.2003.10.005

[30] H. Zhang, X. Jia, Z. Liu and C. Li, "The Low Temperature Preparation of Nanocrystalline $\mathrm{MgAl}_{2} \mathrm{O}_{4}$ Spinel by Citrate Sol-Gel Process," Materials Letters, Vol. 58, No. 10, 2004, pp. 1625-1628. doi:10.1016/j.matlet.2003.09.051

[31] A. Saberi, F. Golestani-Fard, H. Sarpoolaky, M. WillertPorada, T. Gerdes and R. Simon, "Chemical Synthesis of Nanocrystalline Magnesium Aluminate Spinel $\left(\mathrm{MgAl}_{2} \mathrm{O}_{4}\right)$ via Nitrate-Cirate Combustion," Journal of Alloys and Compounds, Vol. 462, No. 1-2, 2008, pp. 142-146. doi:10.1016/j.jallcom.2007.07.101

[32] S. Vivekanandhan, M. Venkateshwarlu and N. Satyanarayana, "Synthesis and Characterization of Nanocrystalline $\mathrm{LiNi}_{0.5} \mathrm{Co}_{0.5} \mathrm{VO}_{4}$ Powders by Citric Acid Assisted Sol-Gel Combustion Process," Journal of Alloys and Compounds, Vol. 462, No. 1-2, 2008, pp. 328-334. doi:10.1016/j.jallcom.2007.08.055

[33] Z. J. Wu, X. B. Zhao, J. Tu, G. S. Cao, J. P. Tu and T. J. Ahu, "Synthesis of $\mathrm{Li}_{1+x} \mathrm{~V}_{3} \mathrm{O}_{8}$ by Citrate Sol-Gel Route at Low Temperature," Journal of Alloys and Compounds, Vol. 403, No. 1-2, 2007, pp. 345-348.

[34] Y. Wu, Y. He, T. Wu, T. Chen, W. Weng and H. Wan, "Influence of Some Parameters on the Synthesis of Nanosized NiO Material by Modified Sol-Gel Method," Materials Letters, Vol. 61, No. 14-15, 2007, pp. 31743178. doi:10.1016/i.matlet.2006.11.018

[35] S. Sahi, A. R. Daud and M. Hashim, "A Comparative Study of Nickel-Zinc Ferrites by Sol-Gel Route and Solid-State Reaction," Materials Chemistry and Physics, Vol. 106, No. 2-3, 2007, pp. 452-456. doi:10.1016/j.matchemphys.2007.06.031

[36] S. A. Mazen, S. F. Mansour and H. M. Zaki, "Some Physical and Magntic Properties of Mg-Zn Ferrite," Crystal Research and Technology, Vol. 38, No. 6, 2003, pp. 471-478. doi:10.1002/crat.200310059

[37] B. D. Cullity, "Elements of X-Ray Diffraction," Addition Wesley, Boston, 1959, p. 132.

[38] S. T. Mahmud, A. K. M. A. Hossain, A. K. M. A. Hakim, M. Seki, T. Kawai and H. Tabata, "Influence of Microstructure on the Complex Permeability of Spinel Type NiZn Ferrite," Journal of Magnetism and Magnetic Materials, Vol. 305, No. 1, 2006, pp. 269-274. 
doi:10.1016/j.jmmm.2006.01.012

[39] B. D. Cullity, "Elements of X-ray Diffraction," Wesley Pub., Co., Boston, 1987, pp. 101-356.

[40] R. G. Gupta and R. G. Mendiratta, "Mossbauer Studies in $\mathrm{Zn}_{x} \mathrm{Mn}_{1-x} \mathrm{Fe}_{2} \mathrm{O}_{4}$ Systems," Journal of Applied Physics, Vol. 48, No. 2, 1977, pp. 845-848. doi:10.1063/1.323642

[41] R. G. Gupta and R. G. Mendiratta, "Hyperfine Field in $\mathrm{Zn}^{2+}{ }_{0.3} \mathrm{Mn}^{2+}{ }_{0.7} \mathrm{Mn}^{3+} \mathrm{y} \quad \mathrm{Fe}^{3+}{ }_{2-\mathrm{y}} \mathrm{O}_{4}$," Journal of Applied Physics, Vol. 48, No. 7, 1977, pp. 2998-3000. doi:10.1063/1.324063

[42] B. P. Ladgaonkar, P. P. Bakare, S. R. Sainkar and A. S. Vaingankar, "Influence of $\mathrm{Nd}^{3+}$ Substitution on Permeability Spectrum of Zn-Mg Ferrite," Materials Chemistry and Physics, Vol. 69, No. 1-3, 2001, pp. 19-24.

[43] L. Vergard, "Die Konstitution der Mischkristalle und Die Raumfüllung der Atome," Zeitschrift für Physik A: Hadrons and Nuclei, Vol. 5, No. 1, 1921, pp. 17-26. doi:10.1007/BF01349680
[44] S. M. Hoque, A. Choudhury and F. Islam, "Characterization of Ni-Cu Mixed Spinel Ferrite," Journal of Magnetism and Magnetic Materials, Vol. 251, No. 3, 2002, pp. 292-303.

[45] R. C. Kumbale. P. A. Shaikh, S. S. Kamble and Y. D. Kolekar, "Effect of Cobalt Substitution on Structural, Magnetic and Electric Properties of Nickel Ferrite," Journal of Alloys and Compounds, Vol. 478, No. 1-2, 2009, pp. 599-603. doi:10.1016/i.jmmm.2005.03.007

[46] P. K. Roy and J. Bera, "Effect of Mg Substitution on Electromagnetic Properties of $\left(\mathrm{Ni}_{0.25} \mathrm{Cu}_{0.20} \mathrm{Zn}_{0.55}\right) \mathrm{Fe}_{2} \mathrm{O}_{4}$ Ferrite Prepared by Auto Combustion Method," Journal of Magnetism and Magnetic Materials, Vol. 298, 2006, p. 38-42.

[47] B. Viswanathan and V. R. K. Murthy, "Ferrite Materials Science and Technology," Narosa Publishing House, New Delhi, 1990. 